and had to walk slowly. He spat up small quantities of bright blood. In the train he gradually became worse, the cough was more violent and he was continually spitting up small lumps of blood and he felt as if he were going to suffocate. He had a distinct recollection of being asked for his ticket but he did not remember seeing the collector. When he arrived at Bradford, 20 minutes after entering the train and five minutes after having given up the ticket, he had to be lifted out of the carriage and was unconscious for from 15 to 20 minutes. During this time he was violently shaken and brandy was poured down his throat. He coughed up lumps and threads of coagulated blood and froth. He gradually came round" and was taken to a private hospital. I saw him in about half an hour. He was breathing rapidly and perspiring freely and was coughing up frothy mucus and small lumps and threads of coagulated blood; some of the latter were ramified and evidently came from the smaller bronchi. The pulse was 125 . There was slight dulness of the base of the left lung and numerous rales and sonorous rhonchi were heard over the bases of both lungs. The upper parts of the lungs were normal. The symptoms gradually cleared up in two days. There were not, and never had been, any symptoms of tuberculosis of the lungs. He said that both lungs felt heavy, especially the left, as though a large piece of lead were pressing on them. For the next three or four weeks the patient coughed up small lumps of red blood. He says that for some months before the attack he expectorated very small pieces of blood now and then. I saw him in June, 1898, and could see distinctly a small blood-clot in one of the papillomata of the vocal cords and there was local hæmorrhage after the removal of the clot. The patient used a formalin spray for some months and the papillomata then practically disappeared and there has been no recurrence up to the present time.

The case is a very peculiar one. Of course, the hæmorrhage may have been of puimonary or intertracheal origin. But the facts that there have been frequent attacks of very slight hæmorrhage without very violent cough, and that I could distinctly see a small blood clot on the papillomata seem to prove that the growths on the edge of the vocal cord were the cause of the hæmorrhage. The violent exertion and excitement in catching the train probably brought on a more severe hæmorrhage than usual and also induced a violent spasm of the glottis which, combined with the blood entering the smaller bronchi, nearly proved fatal. Bradford.

\section{A CASE OF RELAPSING PYREXIA CONTINUING FOR 14 MON'THS UNABATED.}

By Sheffield H. M. Neave, M.R.C.P. Lond.

THE following case now under the care of Dr. Harrington Sainsbury at the Royal Free Hospital is so unusual and so defies treatment that $I$ think it cannot fail to be of general interest.

The patient, a male, 17 years old, was in his usual health till February, 1901. He had spent the whole of his life in a house close to the London Docks. In that month he began to have attacks of pyrexia at regular intervals. The predominant symptom from his own point of view was his intense desire to sleep by day as well as by night. In the intervals of his attacks he felt quite well and used to go to work. He has now been in the Royal Free Hospital for nearly six months and during that period has passed through nine cycles of pyrexia and remissions of fever in 172 days, making an average of 19 days apiece. The actual number of days of remission $(r)$ and days of pyrexia $(p)$ for each of the nine cycles was as follows: $(r) 11,(p) 7 ;(r)$ 12, (p) 7 ; (r) 12, (p) 6 ; (r) 14, (p) 5 ; (r) 14, (p) 6 ; $(r) 13,(p) 6 ;(r) 14,(p) 6 ;(r) 12,(p) 7 ;(r) 14,(p) 6$.

The only physical signs that are in any way permanent are a slight increase of splenic dulness upwards and an enlarged gland in the left axilla. The temperature during an attack rises to a maximum of $105^{\circ} \mathrm{F}$. in the third or fourth day and during the last day it comes down by crisis to $96^{\circ}$ or $97^{\circ}$ with some collapse. The patient has very little discomfort, but is drowsy and bas some bronchitis, his tongue is furred, vomiting occurs at the highest point of temperature, there is some tenderness over the spleen, and the blood count shows a leucocytosis of 16,000. The blood has been examined by various pathologists for malaria parasite, spirillum Obermeyeri, and reaction of Malta fever, all with a negative result. During the remissions the patient appears to be fairly robust though somewhat: anæmic-the blood showing a deficiency of hæmoglobinwithout much wasting, and he feels quite well. Over the. period of six months, however, he has lost weight.

Every chance of a collection of pus has been well considered and investigated; imprimis, cholecystitis with. hepatic intermittent fever has been kept well in view and there is never any sign of jaundice. The cerebro-spinal fluid is sterile. There are no renal symptoms and the urine is normal. A negative result has likewise followed the exploration of the nose, the naso-pharynx, the larynx, and the rectum. There is no affection of the special senses and the fundus oculi and the ear are normal.

Royal Free Hospital, W.C.

\section{A MINUTE PERITONEAL HERNIA THROUGH A CLEFT IN THE XIPHOID CARTILAGE.}

\section{By William Bramwell, M.D., B.Ch. Dub.}

WHILE making a routine examination of a man, aged 36 years, of not very good muscular development, I noticed what looked like a small fatty tumour over the xiphoid. cartilage in the middle line and midway between its attachment to the gladiolus and its lower extremity. The tumour was rather less than half an inch in diameter and was about a quarter of a inch in thickness. On palpation I was surprised to find it become gradually smaller and finally disappear. It also disappeared whenever the patient lay down and there was a slight impulse on coughing. The aperture was a cleft-like perforation in the cartilage with perfectly smooth and symmetrical edges which could be distinctly felt through the skin. It was about half an inch long and a little more than a sixteenth of an inch in width. The patient, who was under treatment for dyspepsia, said that he had noticed the tumour as far back as he could remember but that it had never caused him any pain or inconvenience.

A cleft or perforation in the xiphoid is not an uncommon occurrence but $I$ have never heard or read of a hernia in this situation. This, I judge, was a hernia of a small portion of the parietal peritoneum-that is, a hernia consisting of sac only-and if so is an instructive example of the closeness of apposition of the intestinal contents and of the completeness. with which even the smallest crevice is filled in.

Liverpool.

\section{A attirrox}

\section{HOSPITAL PRACTICE, BRITISH AND FOREIGN.}

Nulla autem est alia pro certo noscendi via, nisi quamplurimas et morborum et dissectionum historias, tum aliorum tum proprias collectas habere, et inter se comparare.-MoraAGNI De Sed. et Caus. Morb., lib. iv., Procemium.

\section{WESTMINSTER HOSPITAL. \\ A CASE OF ACUTE BANTI'S DISEASE. \\ (Under the care of Dr. W. MurRell.)}

THE obscurity which prevails as to the exact nature of the various forms of splenic anæmia can only be dissifated by the careful 1 ecord of many cases. It is not improbable that the term "Banti's disease" includes more than one variety of aisease, but undoubtedly the following case is rightly included under that designation. Dr. Murrell's very full bibliography of the subject is of great value.

A married woman, aged 31 years, residing in Lambeth, was admitted into Westminster Hospital on Jan. 16th, 1902, with a history of hæmatemesis. Mr. A. Mackenzie Hickley, under whose care she had been, reported that she was perfectly well until three days previously when without apparent cause and without premonitory symptoms she vomited three pints of clotted blood. Her previous history was unimportant and there was nothing pointing to hæmophilia in any 